\title{
Tuberculosis with pulmonary involvement in HIV patients
}

\author{
Lígia Fernandes ${ }^{1 *}$, Nuno Marques², Ana Lebre ${ }^{2}$, Joaquim Oliveira² ${ }^{2}$ José Saraiva da Cunha², \\ António Meliço Silvestre ${ }^{2}$ \\ From $16^{\text {th }}$ International Symposium on HIV and Emerging Infectious Diseases \\ Marseille, France. 24-26 March 2010
}

\section{Background}

Tuberculosis (TB) is a leading cause of death worldwide and is closely associated with HIV-infection. The higher probability of spreading TB in patients with pulmonary involvement is always a great concern and demands immediate action.

The aim of this study is to analyze, retrospectively, cases of TB with confirmed pulmonary involvement in the HIV infected population observed in an Infectious Diseases Unit and diagnosed from January 2000 to December 2008.

\section{Results}

The study included 87 patients: $96.5 \%$ HIV-1; $92.0 \%$ Caucasian; 79.3\% male; mean age 41 years [25-76]; 9.2\% were foreigners (5,7\% from Sub-Saharian Africa); HCV co-infection in $49.4 \%$ and $51.7 \%$ with history of drug addiction.

TB was the initial manifestation of HIV infection in $52.9 \%$ and AIDS-defining in $71.3 \%$. TB predominately occurred in late stages of HIV infection $(74.7 \%$ had CD4 $+\mathrm{T}$ cells $\leq 200 / \mathrm{mm} 3$ ). The average time between diagnosis of HIV infection and TB was 3.9 years. Clinical features were mainly respiratory $(71.8 \%)$ and fever (66.3\%). Chest - ray most frequently showed multifocal involvement (50.6\%). Tuberculin test was reactive in 14 cases $(n=27)$. Respiratory secretion culture was positive in $83.9 \%$ - of these, $36.8 \%$ had positive Ziehl-Neelson (ZN) staining. Resistance to 1 or more anti-TB drugs was found in $12.6 \%(n=11)$. There were 2 cases of multirresistance and 1 extensively resistance (XDR). Other pulmonary diseases were associated in $13.8 \%$. HRZE was the most frequent treatment regimen and $14.9 \%$ did not

\footnotetext{
* Correspondence: ligia.r.fernandes@gmail.com

${ }^{1}$ Serviço de Pneumologia, Centro Hospitalar de Coimbra, Coimbra, Portugal
}

complete it due to loss in follow-up. The average time of treatment was 7 months. Mortality rate was $18.4 \%$.

\section{Discussion}

Most TB cases occurred with severe immunossupression and were the first manifestation of HIV infection and AIDS defining in most of the patients. ZN stain of respiratory secretions was negative in a considerable number of cases (63.2\%) whose culture was positive. Mortality and loss to follow-up rates were relevant.

\section{Author details}

Serviço de Pneumologia, Centro Hospitalar de Coimbra, Coimbra, Portugal.

${ }^{2}$ Departamento de Doenças Infecciosas, Hospitais da Universidade de Coimbra, Coimbra, Portugal.

Published: 11 May 2010

doi:10.1186/1742-4690-7-S1-P74

Cite this article as: Fernandes et al:: Tuberculosis with pulmonary involvement in HIV patients. Retrovirology 2010 7(Suppl 1):P74.

Submit your next manuscript to BioMed Central and take full advantage of:

- Convenient online submission

- Thorough peer review

- No space constraints or color figure charges

- Immediate publication on acceptance

- Inclusion in PubMed, CAS, Scopus and Google Scholar

- Research which is freely available for redistribution 